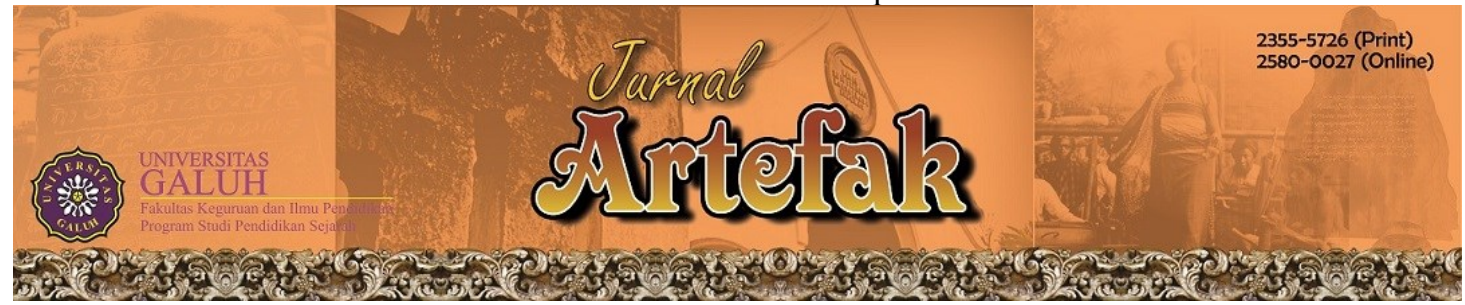

https://jurnal.unigal.ac.id/index.php/artefak/article/view/4669

\title{
KAJIAN IKONOGRAFI DAN IKONOLOGI: RAGAM HIAS PADA BANGUNAN BALE RANTE DI KOMPLEKS MAKAM SUNAN DRAJAT
}

\author{
Angga Fajar Ramadhan ${ }^{1}$, Djuli Djatiprambudi ${ }^{2}$, I Nyoman Lodra ${ }^{3}$ \\ 1, 2, 3 Pendidikan Seni Budaya, Pascasarjana, Universitas Negeri Surabaya, Indonesia \\ E-mail: angga.90kaotan@gmail.com ${ }^{1}$,djulip@yahoo.com², nyomanlodra@unesa.ac.id ${ }^{3}$ \\ Sejarah Artikel: Diterima 1-Maret-2021 Disetujui 15-Maret-2021 Dipublikasikan -April-2021
}

\begin{abstract}
Abstrak
Kompleks makam Sunan Drajat merupakan warisan budaya yang memiliki hubungan dekat dengan periode kehiduan Sunan Drajat. Salah satu bangunan yang menarik dan memiliki konsep filosofis di kompleks makamnya yaitu bangunan bale rante. Bale rante digunakan oleh para Wali Songo untuk berkumpul dan bermusyawarah. Bangunan tersebut berbahan material kayu, berbetuk joglo, beratap limas, berhias ukiran ragam hias dan berasal dari kerajaan Majapahit. Bentuk ragam hias yang menghiasi bangunannya unik dan berbeda dengan bentuk ragam hias pada bangunan kompleks makam lainnya. Tujuan: mendeskripsikan makna ragam hias yang ada pada bangunan bale rante. Metode penelitian: penelitian ini menggunakan metode ikonografi dan ikonologi Erwin Panofsky, dengan tahapan: (1) tahap pra ikonografi, dilakukan dengan mengkaji bentuk penyusun ragam hias pada bangunan bale rante berdasarkan makna faktual dan makna ekspresionalnya. (2) Tahap analisis ikonografi, dilakukan dengan mengidentifikasi makna sekunder yang telah dikaji sebelumnya dengan mengaitkan pada tema dan konsep penciptaan sesuai peristiwa atau sejarah ragam hias tersebut diciptakan. (3) Tahap interpreasi ikonologi, melakukan intuisi sintesis untuk mengungkap makna yang terkandung dalam simbol yang ada dalam ragam hias. Hasil penelitian: Bentuk rantai menyimbolkan kesatuan dan pengayoman. Daun ukel menyimbolkan sumber kehidupan dan kebaikan hati. Pohon hayat dan bunga teratai menyimbolkan keabadian dan penyatuan manusia dengan Allah.
\end{abstract}

Kata Kunci: Kajian Ikonografi dan Ikonologi, Ragam Hias, Bale Rante, Sunan Drajat

\begin{abstract}
The grave complex of Sunan Drajat is a cultural heritage that has a close relationship with the life period of Sunan Drajat. One of the interesting buildings and has a philosophical concept in the tomb complex is the Bale Rante building. Bale rante is used by the Wali Songo for gathering and deliberation. The building is made of wood material, in the form of a joglo, with a pyramid roof, decorated with ornate carvings and comes from the Majapahit kingdom. The forms of decoration that decorate the building are unique and different from the decorative forms in other tomb complex buildings. Purpose: to describe the meaning of the existing decorative styles in the bale rante building. Research method: this study uses Erwin Panofsky's iconography and iconology methods, with the following stages: (1) pre-iconography stage, carried out by examining the decorative forms of the bale rante building based on factual and expressive meanings. (2) The iconographic analysis stage is carried out by identifying secondary meanings that have been previously studied by linking to the themes and concepts of creation according to the events or history of the decorative motifs being created. (3) The iconological interpretation stage involves synthesizing intuition to reveal the meaning contained in symbols that exist in decorations. Result of research: The form of a chain symbolizes unity and protection. Ukel leaves symbolize the source of life and kindness. The tree of life and the lotus flower symbolize the immortality and union of man with Allah.
\end{abstract}

Keyword: Iconographic and Iconological Studies; Ornamental Variety; Bale Rante, Sunan Drajat 


\section{PENDAHULUAN}

Kompleks makam Sunan Drajat merupakan salah satu komplek makam Wali Songo yang berada di Desa Drajat, Kecamatan Paciran, Kabupaten Lamongan, Jawa Timur. Kompleks makam tersebut merupakan salah satu warisan budaya yang ada di Jawa Timur dan ditetapkan oleh BPCB Jawa Timur sebagai benda cagar budaya yang harus dijaga dan dilindungi.

Kompleks makam Sunan Drajat merupakan salah satu benda material yang berhubungan dekat dengan periode kehiduan Sunan Drajat (Tim Peneliti dan Penyusun Buku Sejarah Sunan Drajat, 1998). Kompleks makam Sunan Drajat pada awal pembangunannya hanya memiliki tiga susunan halaman makam. Hal tersebut dipengaruhi oleh kuatnya adat dan tradisi budaya Hindu-Budha saat itu pada pembangunan bangunan suci. Kompleks makam Sunan Drajat mengambil konsep bangunan suci dari kompleks Candi Penataran, yang memiliki tiga susunan halaman dan meletakkan bangunan yang paling sakral pada halaman yang paling tinggi dan paling belakang. Adanya gempa pada tahun 1950 menyebabkan rusaknya bangunan di kompleks makamnya. Pemugaran dilakukan oleh masyarakat Drajat dan merubah susunan halaman yang semula tiga susun halaman menjadi tujuh susun halaman.

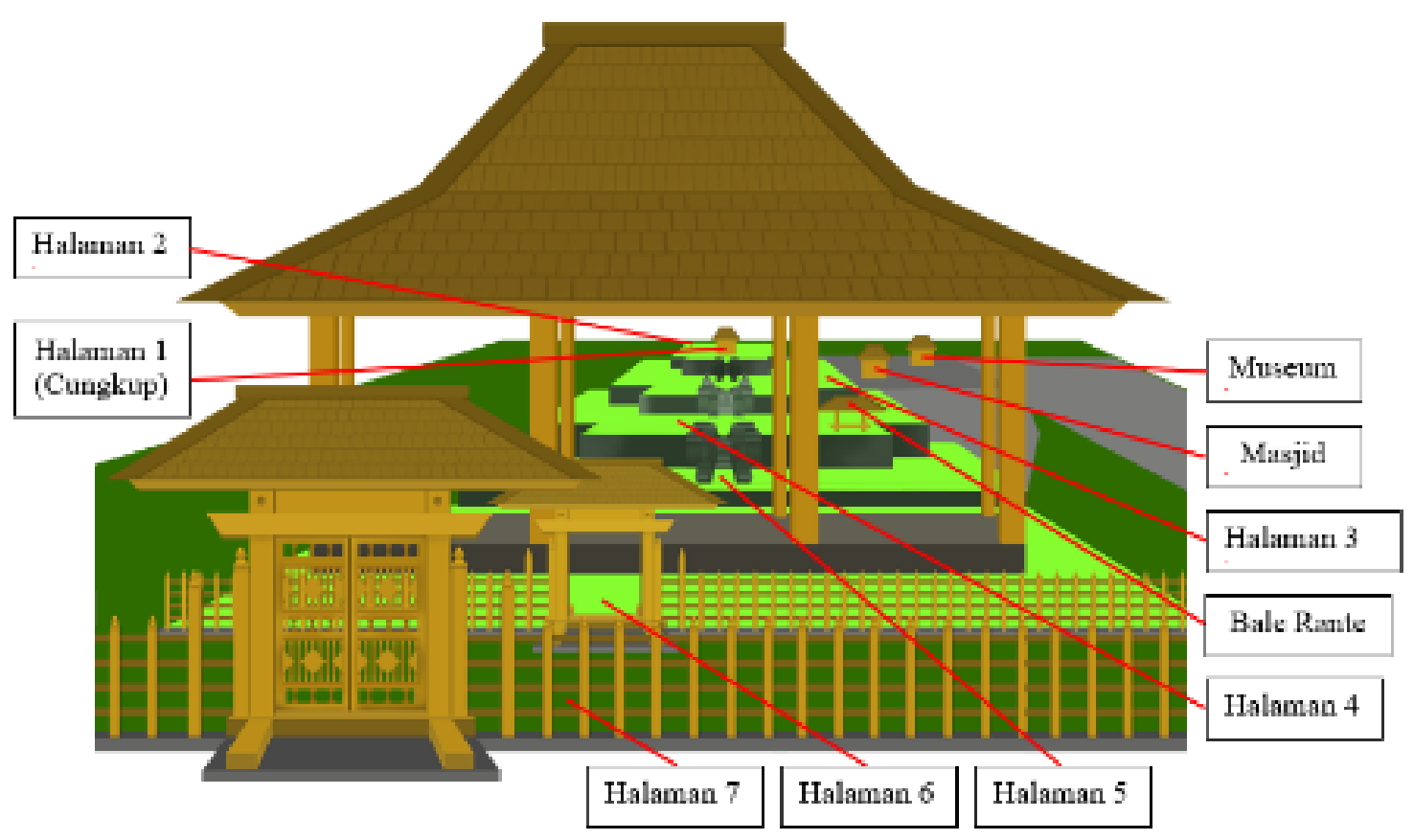

Gambar 1. Denah Kompleks Makam Sunan Drajat

(Sumber: Desain Pribadi, 2020)

Bahan material yang ada pada kompleks makam Sunan Drajat memadukan antara bahan material batu dan kayu. Arsitektur bangunan yang menggunakan material batu berupa bangunan gapura paduraksa pada susunan halaman kedua dan gapura belah atau candi bentar pada susunan halaman ketiga dan keempat. Arsitektur bangunan yang menggunakan bahan material kayu berupa bangunan gapura paduraksa, pada susunan halaman keenam dan ketujuh, cungkup makam Sunan Drajat pada halaman pertama dan bale rante pada halaman keempat. 

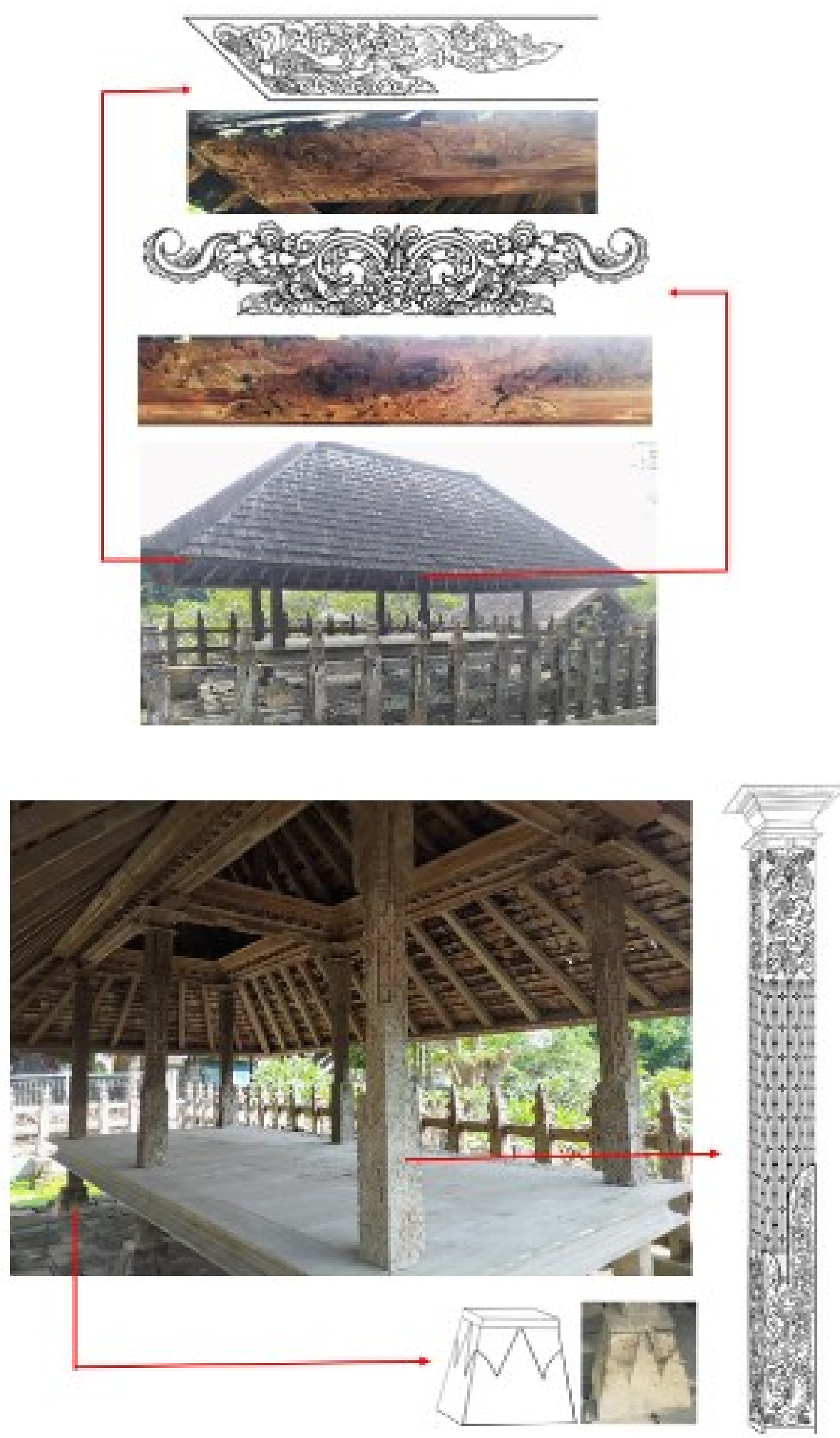

Gambar 2. Bangunan Bale Rante Tampak Luar dan Dalam

(Sumber: Foto Pribadi, 2020)

Bangunan bale rante juga dijumpai pada kompleks makam Sunan Bonang. Namun secara bentuk bangunan dan bentuk ukiran ragam hiasnya berbeda dengan bale rante yang ada di Kompleks makam Sunan Drajat. Adapun bentuk ukiran ragam hias pada bale 
rante di Kompleks makam Sunan Drajat memiliki bentuk yang unik, menarik dan memiliki konsep filosofis.

\section{METODE PENELITIAN}

Penelitian ini menggunakan metodologi penelitian kualitatif deskriptif dengan metode analisis ikonografi dan ikonologi Erwin Panofsky. Untuk mengungkap makna dibalik suatu karya seni rupa (ragam hias) sesuai dengan konsep penciptaannya, peneliti menggunakan pendekatan sejarah. Panofsky menjelaskan tahapan yang digunakan untuk mengungkap makna dibalik suatu karya yaitu pra ikonografi (pre iconographical description), analisis ikonografi (iconographical analysis) dan interpretasi ikonologis (iconological interpretation) (Panofsky, 1955).

Tahap pra ikonografi merupakan tahap mengidentifikasi aspek visual bentuk karya seni dari makna faktual dan makna ekspresionalnya. Makna faktual merupakan mengidentifikasi bentuk visual yang tampak pada objek penelitian dan perubahannya melalui aksi atau peristiwa tertentu. Dengan mengidentifikasi garis, bentuk, warna, material, teknik, serta objek-objek representasi alami atau buatan seperti tumbuhan, hewan, manusia dan benda perlengkapan. Sedangkan makna ekspresional merupakan empati dari pengamatan peneliti pada kebiasaan dan rasa familiar dari objek dan peristiwa. Mengidentifikasi hubungan antara bentuk-bentuk dan peristiwa-peristiwa yang dapat menjadikan kualitas ekspresional sebagai karakter atau bahasa tubuh objek (Panofsky, 1955).

Tahap analisis ikonografi merupakan tahap mengidentifikasi makna sekunder. Dengan melihat hubugan antara bentuk visual dan ekspresinya (hasil pra analisis) dengan tema dan konsep penciptaannya. Prinsip korektif yang digunakan dalam tahap ini ialah pada interpretasi sejarah tipe. Sejarah tipe merupakan beragam kondisi sejarah, objek, serta peristiwa yang ternyatakan lewat bentuk. Dengan memahami sejarah tipe dapat menambah maupun mengkoreksi pengetahuan berdasarkan sumber literatur yang terjadi dari beragam kondisi sejarah, tema atau konsep khusus yang ternyatakan lewat objek bentuk (Panofsky, 1955).

\begin{tabular}{|c|c|c|}
\hline No. & Objek Interpretasi & Aksi Interpretasi \\
\hline I. & $\begin{array}{l}\text { Pokok bahasan pri- } \\
\text { mer atau alami (A) } \\
\text { faktual, (B) ekspre- } \\
\text { sional, menyusun } \\
\text { dunia motif artistik. }\end{array}$ & $\begin{array}{l}\text { Deskripsi pra- } \\
\text { ikonografi (anal- } \\
\text { isis pseudo-for- } \\
\text { mal) }\end{array}$ \\
\hline II. & $\begin{array}{l}\text { Pokok bahasan se- } \\
\text { kunder atau konven- } \\
\text { sional, menyusun } \\
\text { dunia gambar, cerita } \\
\text { dan alegori. }\end{array}$ & $\begin{array}{l}\text { Analisis ikono- } \\
\text { grafis }\end{array}$ \\
\hline III. & $\begin{array}{l}\text { Makna intrinsik atau } \\
\text { isi, menyusun dunia } \\
\text { nilai 'simbolis' }\end{array}$ & $\begin{array}{l}\text { Interpretasi iko- } \\
\text { nologis }\end{array}$ \\
\hline
\end{tabular}

\begin{tabular}{|c|c|}
\hline Alat Interpretasi & $\begin{array}{l}\text { Prinsip Korektif dari } \\
\text { Interpretasi (Sejarah } \\
\text { Tradisi) }\end{array}$ \\
\hline $\begin{array}{l}\text { Pengalaman praktis } \\
\text { (rasa familier dengan } \\
\text { objek dan peristiwa) }\end{array}$ & $\begin{array}{l}\text { Sejarah seni (pan- } \\
\text { dangan ke dalam cara } \\
\text { di mana, menurut } \\
\text { kondisi sejarah yang } \\
\text { bervariasi, objek dan } \\
\text { peristiwa dinyatakan } \\
\text { alam bentuk }\end{array}$ \\
\hline $\begin{array}{l}\text { Pengetahuan tentang } \\
\text { sumber literal (rasa } \\
\text { familier dengan tema } \\
\text { dan konsep khusus) }\end{array}$ & $\begin{array}{l}\text { Sejarah tipe/jenis } \\
\text { (pandangan terha- } \\
\text { dap cara di mana, di } \\
\text { bawahkondisi sejarah } \\
\text { yang bervariasi, tema } \\
\text { dan konsep khusus } \\
\text { dinyatakan melalui } \\
\text { objek dan peristiwa) }\end{array}$ \\
\hline $\begin{array}{l}\text { Intuisi sintetis (rasa } \\
\text { familier dengan ten- } \\
\text { densi esensial dari } \\
\text { pikiran manusia); } \\
\text { dikondisikan oleh } \\
\text { psikologi personal } \\
\text { dan 'toclfanscharumg' }\end{array}$ & $\begin{array}{l}\text { Sejarah gejala kul- } \\
\text { tural (pandangan ke } \\
\text { dalam cara di. mana } \\
\text { di bawah kondisi se- } \\
\text { jarah yang bervariasi, } \\
\text { tendensi umum dan } \\
\text { esensial dari pikiran } \\
\text { manusia dinyatakan } \\
\text { melalui tema dan } \\
\text { konsep khusus) }\end{array}$ \\
\hline
\end{tabular}

Gambar 3. Tahapan Kajian Ikonografi dan Ikonologi

(Sumber: Panofsky, 1955:40-41)

Tahap interpretasi ikonologi merupakan pemahaman deskripsi pra ikonografi dan 
analisis ikonografi. Tahap ini membutuhkan mental yang disebut intuisi sintesis dalam memahami simbol. Intuisi sintesis menyangkut tendensi esensial pemikiran psikologi personal dan pendangan hidup pencipta karya (Panofsky, 1955)

Teknik penelitian yang digunakan dalam penelitian ini yaitu dengan melakukan observasi dan wawancara. Observasi dilakukan dengan mengamati, mencatat dan mendokumentasikan secara langsung bentuk ukiran ragam hias pada bangunan bale rante di kompleks makam Sunan Drajat. Wawancara dilakukan untuk mendapatkan informasi terkait dengan sejarah, ajaran-ajaran Sunan Drajat dan makna ragam hias pada bangunan bale rante. Hasil observasi dan wawancara akan dianalisis sesuai dengan tahapan metode ikonografis dan ikonologis

\section{HASIL PENELITIAN DAN PEMBAHASAN}

\section{Bale Rante}

Bale rante merupakan bangunan yang digunakan oleh para Wali Songo untuk melakukan musyawarah. Konsep bangunan tersebut juga sama seperti konsep bangunan pendopo rumah tradisonal Jawa. Pendopo digunakan oleh keluarga, kerabat ataupun tetangga untuk melakukan musyawarah. Bale rante merupakan salah satu bangunan yang ada di kompleks makam Sunan Drajat yang berasal dari kerajaan Majapahit (Rahmat, 2020). Bangunan tersebut merupakan bangunan peninggalan kerajaan Majapahit dengan konstruksi bahan material kayu yang masih tersisa hingga saat ini.

Bale rante berbentuk pendopo dengan atap limas. Memiliki enam tiang dan beralas persegi panjang. Ukuran bangunan mempunyai panjang 3 meter, lebar 1,5 meter dan tinggi 2,5 meter. Memiliki ukiran ragam hias pada bagian umpak, tiang, pelipit luar bawah atap, dan bagian kerangka dalam. Bagian kerangka dalam memiliki ragam hias yang serupa dengan bagian pelipit luar dan tiang bangunan. Bentuk motif ragam hias yang ada bermotif flora (tumbuhan), geometris dan benda teknologis. Peneliti memilih empat ragam hias yang menjadi pkok bahasan dalam penelitian.

\section{Pra Ikonografi}

Tahap pra ikonografis dalam penelitian ini mengkaji bentuk penyusun ragam hias pada bangunan bale rante berdasarkan makna faktual dan makna ekspresionalnya.

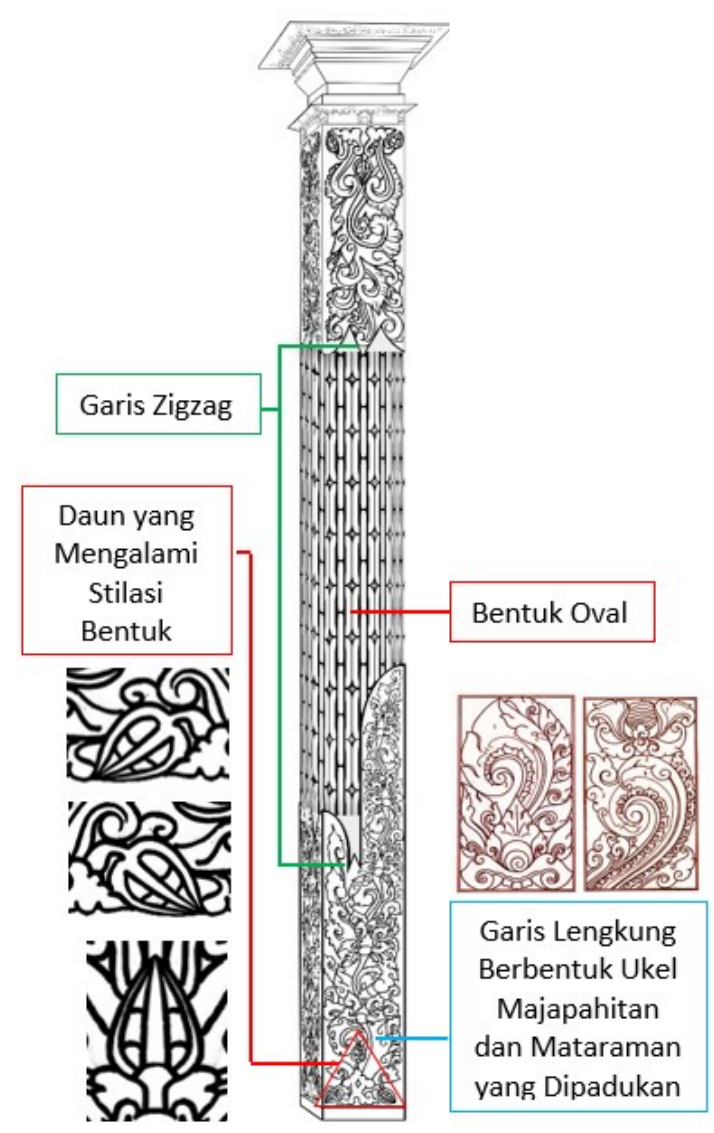

Gambar 4. Tiang Bangunan

(Sumber: Desain Pribadi, 2020)

Gambar 4 memiliki bentuk ragam hias flora, dan benda teknologis. Memiliki garis lengkung, zigzag dan oval. Garis lengkung terlihat menonjol pada ragam hias berbentuk ukel gaya Majapahitan dan Mataraman. Garis zigzag terlihat pada ragam hias geometris bagian atas dan tengah dengan bentuk tumpal. 
Garis oval terlihat pada bentuk ragam hias benda teknologis dengan bentuk rantai yang terjalin antara satu dengan yang lain. Rantai berbentuk vertikal ke atas berjumlah sembilan rantai dan memutar melingkar berjumlah sembilan ratai. Bahan yang digunakan berbahan kayu tanpa menggunakan pewarnaan. Teknik yang digunakan dalam pembuatan menggunakan teknik ukir.

Bentuk ekspresi terlihat pada motif Majapahitan dan Mataraman yang mengalami penambahan dan pengurangan bentuk (perpaduan motif). Selain itu bentuk rantai yang umunya hanya sambung-menyambung yang diekspresikan dengan disusun berjalin, vertikal dan memutar melingkar membentuk konstruksi tiang. Bentuk ragam hias yang diekspresikan pada seluruh tiang bangunan sama pada setiap sudut-sudutnya, kecuali dua tiang tengah bangunan. Garis zigzag pada bagian tengah lebih pendek dan sama seperti bentuk ragam hias pada bagian atas.

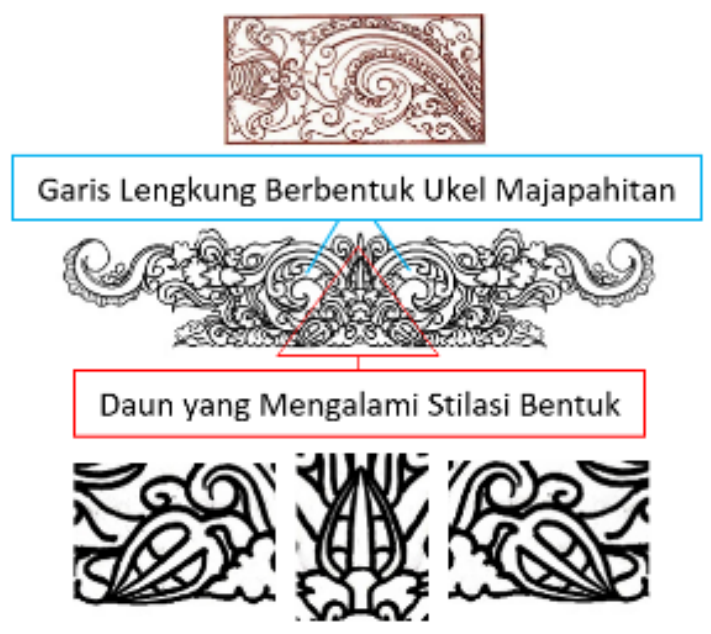

Gambar 5. Ragam Hias pada Pelipit Bawah Atap Bangunan Bagian Tengah

(Sumber: Desain Pribadi, 2020)

Gambar 5 berbetuk ragam hias flora. Memiliki garis lengkung, sangat menonjol terlihat pada bentuk ragam hias berbentuk ukel gaya Majapahitan. Memiliki pusat pada bagian tengah membentuk bidang segitiga dan simetris pada bagian kanan dan kirinya.
Material bahan yang digunakan berbahan kayu tanpa menggunakan pewarnaan. Teknik yang digunakan dalam pembuatan menggunkan teknik ukir.

Bentuk ekspresi terlihat pada bentuk daun yang mengalami stilasi bentuk dengan lebih sederhana. Membentuk pola dasar segitiga pada bagian atas-kanan-kiri (sudutsudutnya). Selain itu motif Majapahitan yang digunakan juga mengalami penambahan dan pengurangan bentuk, disusun bersingungan membentuk simetris. Ragam hias ini ditempatkan pada setiap pusat (tengah) pelipit bawah atap bangunan.

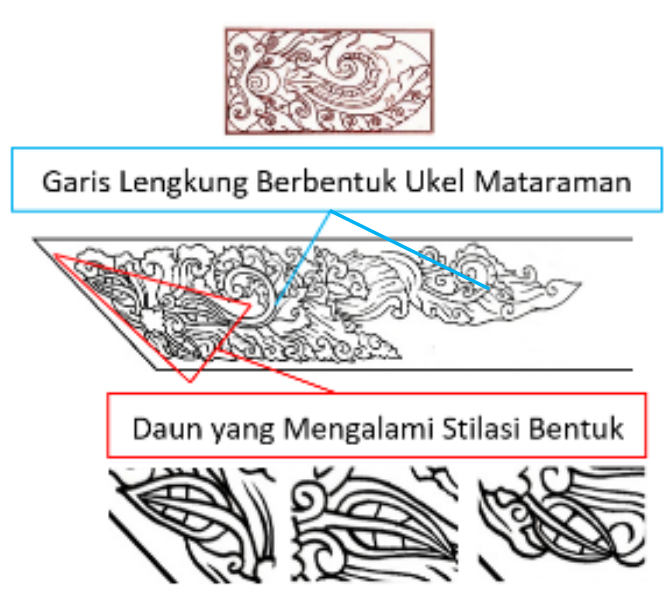

Gambar 6. Ragam Hias pada Pelipit Bawah Atap Bangunan Bagian Sudut.

(Sumber: Desain Pribadi, 2020)

Gambar 6 berbetuk ragam hias flora. Memiliki garis lengkung, sangat menonjol terlihat pada bentuk ragam hias berbentuk ukel gaya Mataraman. Memiliki pusat pada bagian sudut (menyudut). Material bahan yang digunakan berbahan kayu tanpa menggunakan pewarnaan. Teknik yang digunakan dalam pembuatan menggunakan teknik ukir.

Bentuk ekspresi terlihat pada bentuk daun yang mengalami stilasi bentuk dengan lebih sederhana. Membentuk pola dasar segitiga pada bagian sudutnya (menyudut). Selain itu, motif Mataraman yang digunakan juga mengalami penambahan dan pengurangan bentuk. Bentuk global motif 
yang ada menyesuaikan dengan bentuk dasar pelipit bangunan bagian sudut. Ragam hias ini ditempatkan pada setiap sudut-sudut pelipit bawah atap bangunan.

Gambar 7 berbetuk ragam hias flora. Menunjukkan penggunaan garis lurus, lengkung dan zigzag. Garis lurus terlihat pada bagian atas, membentuk kuncup bunga. Garis lengkung dan zigzag terlihat pada bagian tengah, membentuk kelopak bunga. Material bahan yang digunakan berbahan batu tanpa menggunakan pewarnaan. Teknik yang digunakan dalam pembuatan menggunakan teknik pahat.

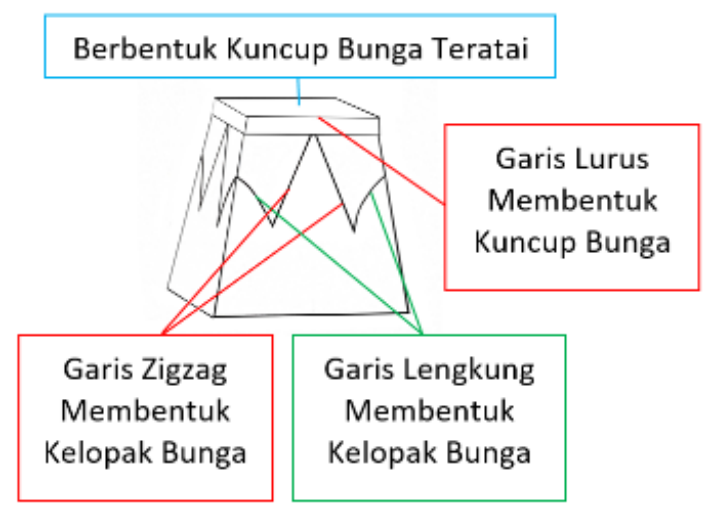

Gambar 7. Ragam Hias pada Umpak

Bangunan

(Sumber: Desain Pribadi, 2020)

Bentuk ekspresi terlihat pada bentuk global objek yang menunjukkan ekspresi bentuk kuncup bunga teratai. Ide penciptaan didasarkan pada bentuk kuncup bunga teratai, yang mengalami stilasi bentuk dengan lebih sederhana. Kuncup bunga teratai diekspresikan dengan bagian atas datar, selain itu kelopak bunga diekspresikan dengan perpaduan garis lengkung dan zigzag.

\section{Analisis Ikonografi}

Tahap analisis ikonografi dalam penelitian ini merupakan tahap identifikasi makna sekunder yang telah dikaji sebelumnya pada tahap pra ikonografi. Dengan mengaitkan tema dan konsep penciptaan sesuai peristiwa atau sejarah ragam hias tersebut diciptakan.

Jika dikaitkan dengan peristiwa dan sejarah bangunan yang ada di kompleks makam, kompleks makam Sunan Drajat sezaman dengan pemerintahan kerajaan Majapahit akhir. Fakta historis juga menunjukkan bangunan bale rante merupakan bangunan yang berasal dari kerajaan Majapahit yang terbuat dari konstruksi berbahan kayu. Bangunan tersebut dibawa dari Majapahit ke makam Sunan Drajat. Jika dikaitkan dengan kegunaan bangunan, bangunan tersebut digunakan oleh para Wali Songo untuk melakukan musyawarah (Rahmat, 2020). Hal tersebut menunjukkan bagunan bale rante telah ada sebelum wafatnya Sunan Drajat pada tahun 1522 M (Sunyoto, 2018). Bagitu juga ragam hias yang ada pada bangunan bale rante, ide penciptaannya masih didasarkan pada budaya Majapahit yang bernafaskan Hindu-Budha.

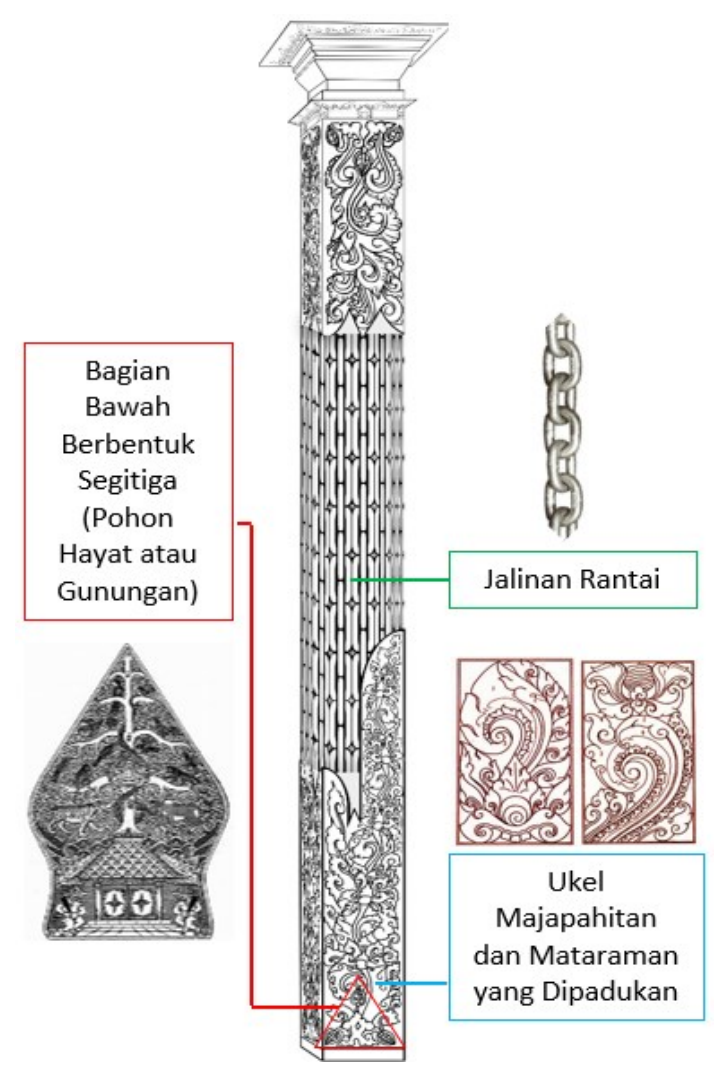

Gambar 8. Tiang Bangunan

(Sumber: Desain Pribadi, 2020) 
Bentuk ukiran ragam hias pada gambar 8 menunjukkan perpaduan ragam hias flora dan benda teknologis yang mengalami stilasi bentuk. Pertama, bentuk rantai yang terjalin antara satu dengan yang lain, berbentuk vertikal ke atas berjumlah sembilan rantai dan memutar melingkar berjumlah sembilan rantai. Bilangan sembilan berhubungan dengan sebuah falsafah Sunan Drajat "wiworo songo". Wiworo songo merupakan sembilan lubang yang ada pada tubuh manusia. Namun ada dua yang lubang tetapi tidak berlubang. Adapun kesemua lubang tersebut (1) mulut, (2) dua lubang mata, (3) telinga, (4) hidung, (5) dubur, (6) kemaluan (7) pusar dan (8) ubun-ubun. Ketujuh yang lubang itulah yang menjadi sebab-sebab manusia melakukan dosa. Dengan menjaga (reksa) ketujuh lubang yang ada tersebut akan mendekatkan dan menjadikan manusia lebih bertakwa kepada Allah (manunggaling kawula gusti) (Rahmat, 2020). Jumlah sembilan rantai juga dikaitkan dengan jumlah Wali Songo, yang berjumah sebilan orang. Selain itu jika dikaitkan dengan jumlah bilangan huruf kata "n-u-s-a-n-t-a-r-a ataupun i-n-d-o-n-e-s-i-a" juga berjumlah sembilan (Sunyoto, 2018).

Kedua, motif ukir yang khas ukel Majapahitan dan Mataraman digunakan sesuai semangat zamannya (perpaduan motif). Berada pada bagian atas dan bawah dari keempat sisi tiangnya. Ragam hias yang memiliki bentuk yang mengacu pada tumbuhan juga memiliki fungsi sakral atau simbolik (Guntur, 2004). Tumbuhan menjadi sumber kehiduan bagi makhluk lainnya, sebagai karunia yang memiliki nilai tinggi kaitannya dengan hidup manusia (Toekio, 2000). Lung-lungan (motif ukel) memiliki makna simbolik kejayaan dan keluhuran (Sadah et al., 2018).

Ketiga, pusat ragam hias berbentuk segitiga berada pada bagian atas dan bawah dengan stilasi bentuk daun yang membentuk pohon hayat. Pohon hayat merupakan pohon keramat yang menyatukan dunia atas dan dunia bawah melambangkan keseutuhan dan keesaan tertinggi (Sunaryo, 2009). Pohon hayat di Jawa juga dikaitkan dengan gunungan, dengan ciri khas bentuk dasar segitiga yang meruncing ke atas dengan sedikit melengkung pada bagian bawah. Gunungan merupakan tempat keramat yang dianggap sebagai tempat para roh dan dewa (Sunaryo, 2009). Gambar pohon, binatang dan semua yang ada di dalam gunungan menggambarkan kehidupan manusia berdimensi kosmik (menjunjung tinggi dan memelihara alam semesta). Gunungan dengan pewarnaan warna-warninya menunjukkan bahwa eksistensi manusia itu tidak sendirian. Manusia hidup dipengaruhi oleh alam semsta, hewan, tumuhan, serta segala sesuatu baik yang tampak maupun yang tidak tampak (Yumarma, 2012). Relasi hubungan yang dapat dibangun dengan baik akan membuat manusia bisa mengarungi kehidupnya dengan bahagia dan sejahterah.

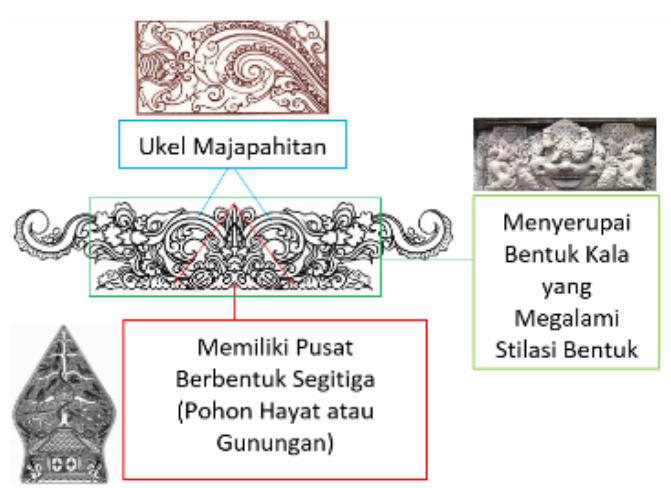

Gambar 9. Ragam Hias pada Pelipit Bawah Atap Bangunan Bagian Tengah (Sumber: Desain Pribadi, 2020)

Bentuk ukiran ragam hias pada gambar 9 menunjukkan perpaduan ragam hias flora yang mengalami stilasi bentuk. Pertama, bentuk secara global, ragam hias tersebut menyerupai bentuk Kala. Hal tersebut dikuatkan juga dengan penempatan ragam hias yang berada pada bagian tengah pelipit bawah atap. Posisi tersebut sama persis dengan posisi Kala yang berada pada pintu masuk utama candi. Namun penggambaran makhluk hidup 
dihindari sesuai dengan norma-norma ajaran Islam. Pedoman penciptaan ragam hias dilakukan dengan menyamarkan bentuk yang sangat jauh dari bentuk aslinya atau perupaannya (abstraksi bentuk) Motif Kala memiliki fungsi sebagai penjaga gerbang dan mengusir makhuk jahat. (Sunaryo, 2009). Dalam ajaran agama Hindu, Kala adalah putera Dewa Siwa yang bergelar sebagai dewa penguasa waktu. Kala merupakan simbol bahwa siapa pun tidak dapat melawan hukum karma. Apabila sudah waktunya seseorang meninggalkan dunia fana, maka pada saat itu pula Kala akan datang menjemputnya (Halim, Andre \& Herwindo, 2017).

Kedua, pusat ragam hias berbentuk segitiga berada pada bagian pusat (tengah) dengan stilasi daun yang membentuk pohon hayat. Pohon hayat merupakan pohon keramat yang menyatukan dunia atas dan dunia bawah melambangkan keseutuhan dan keesaan tertinggi (Sunaryo, 2009). Pohon hayat di Jawa juga dikaitkan dengan gunungan, dengan ciri khas bentuk dasar segitiga yang meruncing ke atas dengan sedikit melengkung pada bagian bawah. Gunungan merupakan tempat keramat yang dianggap sebagai tempat para roh dan dewa (Sunaryo, 2009).

Ketiga, memiliki dua ukel berbentuk Majapahitan yang menyatu pada ujung pangkalnya. Dua ukel Majapahitan yang saling bertolak belakang dalam simbol tradisi menunjukkan pola dualisme tunggal (pertentangan). Konsep pertentangan menunjukkan adanya dualisme yang berbeda namun memiliki ikatan. Seperti langit dan bumi, hidup dan mati, baik da buruk, malam dan siang, laki-laki dan perempuan. Konsep dualisme tunggal memiliki simbol kelahiran kembali (Sumardjo, 2006).

Bentuk ukiran ragam hias pada gambar 10 menunjukkan perpaduan ragam hias flora yang mengalami stilasi bentuk. Motif ukir yang khas Mataraman berada pada bagian Pelipit Bawah Atap Bangunan Bagian Sudut. Tumbuhan menjadi sumber kehiduan bagi makhluk lainnya, sebagai karunia yang memiliki nilai tinggi kaitannya dengan hidup manusia (Toekio, 2000). Lung-lungan (motif ukel) memiliki makna simbolik kejayaan dan keluhuran (Sadah et al., 2018).

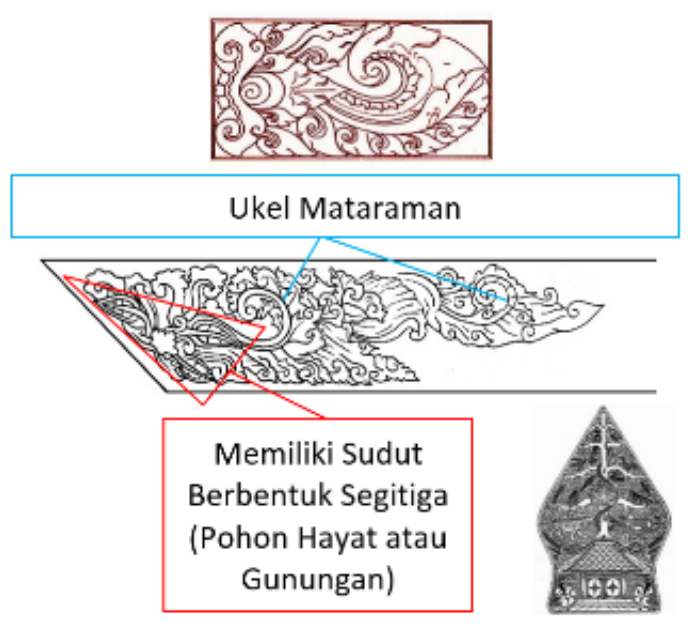

Gambar 10. Ragam Hias pada Pelipit Bawah Atap Bangunan Bagian Sudut. (Sumber: Desain Pribadi, 2020)

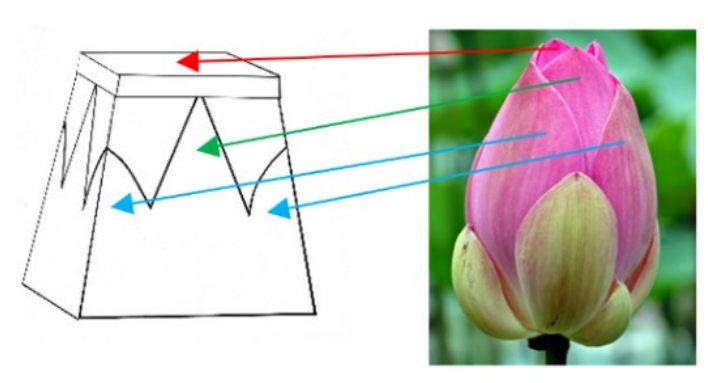

Gambar 11. Ragam Hias pada Umpak Bangunan

(Sumber: Desain Pribadi, 2020)

Bentuk ukiran ragam hias pada gambar 11 menunjukkan bentuk kuncup bunga teratai yang mengalami stilasi bentuk. Kuncup teratai dalam mitologi india dipandang sebagai tanaman suci dan diyakini memiliki daya magis untuk memberikan pencerahan, menolak bala, (Guntur, 2004).

Bunga teratai dalam perupaan motif memiliki tiga bentuk, padma, utpala dan kumuda. Namun yang sesuai dengan bentuk ragam hias pada gambar 11 berbetuk padma. Memiliki kuntum bunga berwarna merah, 
dengan bentuk kuncup yang memiliki ukuran yang lebih besar serta bungnya menjulang. Teratai merah (padma) melambangkan keabadian, kekekalan dan kelanggengan. (Tim Peneliti dan Penyusun Buku Sejarah Sunan Drajat, 1998).

Bunga teratai dalam pandangan Islam, terutama dalam ajaran Sunan Drajat berisi tunjung kang tanpa telaga. Bunga teratai yang dapat hidup tanpa adanya telaga. Sebuah bunga yang memiliki kedudukan sudah tidak tergantung lagi pada lumpur eksistensi dunia, artinya teratai tersebut menggambarkan capaian spiritual dalam taraf yang sudah melampaui batasan dunia yang terbatas. Secara filosofis ungkapan tersebut melukiskan hakikat kedudukan manusia sempurna (insan kamil) yang dianggap atau sebagai tamsil pantulan dari Dzat Mutlak (Nizam et al., 2018).

\section{Interpretasi Ikonologi}

Tahap interpretasi ikonologi dalam penelitian ini dilakukan dengan memahami deskripsi pra ikonografi dan analisis ikonografi yang telah dibahas sebelumnya. intuisi sintesis dilakukan untuk mengungkap makna yang terkandung dalam simbol yang ada pada ragam hias. Pemahaman mengenai makna intrinsik yang terdapat dalam sebuah objek dapat menunjukkan ajaran spiritualitas atau filosofis tertentu (Rony, 2014).

Bentuk rantai berjalin membentuk garis vertikal dan memutar, serta memiliki bilangan sembilan memiliki nilai filosofis yang berupa kesatuan hubungan para Waliullah dalam membangun Agama Islam (melakukan Islamisasi kepada penduduk Jawa). Selain itu, rantai juga memiliki simbol pengayoman. Dilihat dari falsafah-falsafah yang dibuat, menunjukkan peran Wali Songo mengayomi masyarakat Jawa. Seperti Falsafah dalam ajaran Sunan Drajat, (1) wenehono teken marang wong kang wuto (berikan tongkat pada orang yang buta), (2) wenehono mangan marang wong kang keluwen (berikan makanan pada orang yang kelaparan), (3) wenehono payung marang wong kang kaudanan (berikan payung pada orang yang kehujanan), (4) wenehono sandang marang wong kaudan (berikan pakaian pada orang yang tidak berpakaian).

Falsafah lain dalam ajaran Sunan Drajat yang mengambil sifat bunga lotus atau teratai memiliki falsafah tunjung kang tanpa telaga (bunga teratai yang dapat hidup tanpa adanya telaga atau air). Berisi hakekat kedudukan manusia sempurna (insan kamil). Manusia yang tetap hidup langgeng atau abadi dengan penyatuan dirinya dengan Tuhan (manunggaling kawula gusti). Konsep manunggaling kawula gusti jika dikaitkan dengan konteks zaman Islam (Wali Songo), dimaknai sesuai dengan konsep yang diambil dari Al-Qur'anul Karim. Merujuk pada surat Al-Baqoroh ayat 115 berbunyi $f a$ ainama $\bar{a}$ tuwallu fa samma waj-hullāh (Kemanapun kamu menghadap di sanalah wajah Allah). Selain itu juga merujuk pada surat Al-Hadiid ayat 4 berbunyi wa huwa ma'akum aina mā kuntum (Dan Dia bersama kamu di mana saja kamu berada). Konsep yang diambil dari AlQur'anul Karim diambil Wali Songo untuk merubah konsep yang ada sebelumnya.

Kemudian 7 wejangan dari Sunan Drajat (saptopiweling) secara tutur tinular yang terkandung di dalam setiap pintu masuk halaman (Rahmat, 2020) memiliki falsafah (1) memangun resep tyasing sasomo, (selalu membuat senang hati orang lain), (2) jroning suka kudu eling lan waspada (dalam suasana riang kita harus tetap ingat dan waspada), (3) laksmitaning subrata tan nyipta marang pringgabayaning lampah (dalam perjalanan untuk mencapai cita-cita luhur kita tidak perduli dengan segala bentuk rintangan), (4) meper hardaning pancadriya (kita harus selalu menekan gelora nafsu-nafsu), (5) mulya guna panca waktu (suatu kebahagiaan lahirbatin hanya bisa kita capai dengan sholat lima waktu), (6) heneng- hening-henung (dalam keadaan diam kita akan memperoleh keheningan dan dalam keheningan itulah kita akan mencapai cita-cita luhur), (7) segoro 
ombak pinanah tunggal atau truna ing samudra wirayang $j i$ (terhadap gejolak kehidupan hendaknya dipahami sebagai perwujudan (kehendak) tuhan, karena Allah dengan segala ciptanya, kembalinya hanya kepada-Nya yang maha Esa) (Sadah et al., 2018).

Bentuk daun ikal khas Majapahitan dan Mataraman memiliki nilai filosofi yang berupa sumber kehidupan. Tumbuhan merupakan salah satu sumber kehidupan bagi kelangsungan hidup manusia. Jika dikaitkan dengan letak goegrafis Nusantara dan sezaman adanya Wali Songo, alam Nusantara dikaruniai Allah dengan sumber makanan yang melimpah. Kekakyaan alam yang ada di Nusantara sangat cukup untuk kelansungan hidup yang makmur. Jika dilihat dari bentuknya, simbol daun ikal mengandung nilai-nilai berupa kebaikan hati, manusia harus memiliki sifat lemah lembut, lues dan berbudi pekerti luhur.

Bentuk pohon hayat atau gunungan memiliki nilai filosofis yang berupa penyatuan dunia bawah dengan dunia atas. Untuk dapat hidup sejahterah dan selamat di dunia maupun di akhirat, manusia harus bisa membangun relasi yang baik dengan Tuhan. Hubungan tersebut digambarkan dalam visualisasi gunungan wayang. Alam dunia atau dunia manusia digambarkan paling bawah dan hanya sedikit, manunjukkan dunia material yang fana. Untuk mencapai kesejahteraan dan keselamatan, manusia harus melewati berbagai rintangan dan cobaan yang digambarkan pada bagian tengah gunungan. Manusia harus melewati rintangan dan cobaan untuk menuju tempat yang paling tinggi. Semakin tinggi yang dilalui manusia, bentuk gunungan akan semakin mengecil dan meruncing. Puncak gunugan menggambarkan dunia atas (Tuhan) yang sakral dan penuh dengan kekuatan magis.

\section{KESIMPULAN}

Bale rante merupakan bangunan suci yang berasal dari kerajaan Majapahit. Bahan konstruksi bangunan menggunakan bahan material kayu. Bangunan tersebut dihiasi dengan ragam hias bermotif flora, geometris dan benda teknologis. Menggunakan motifmotif yang masih bernafaskan Hindu-Budha, namun ide penciptaan serta bentuk yang dihasilkan mengalami stilasi dan menyesuaikan dengan konsep ajaran Agama Islam.

Bentuk rantai menyimbolkan kesatuan dan pengayoman. Daun ukel menyimbolkan sumber kehidupan dan kebaikan hati. Pohon hayat dan bunga teratai menyimbolkan keabadian dan penyatuan manusia dengan Allah. Pengkajian menggunakan metode ikonografi dan ikonologi dengan topik ragam hias pada bangunan bale rante merupakaan telaah bahasa rupa tradisi pada seni hias bangunan (arkeologi). Penelitian yang dilakukan dapat memahami tema ataupun ide penciptaan dengan mengungkap makna bentuk visualnya dan makna yang terkandung di dalamnya sesuai dengan semangat zamannya.

\section{DAFTAR PUSTAKA}

Guntur. (2004). Ornamen Sebuah Pengantar. STSI Press Surakarta.

Halim, A \& Herwindo, R. P. (2017). The Meaning of Ornaments in the Hindu and Buddhist Temples on the Island of Java (Ancient - Middle - Late Classical Eras). Riset Arsitektur (RISA), 1(02), 170-191.

https://doi.org/10.26593/risa.v1i02.239 1.170-191

Nizam, A., Nugraha, W., \& Gustami, S. P. (2018). Eksistensi Ragam Hias Sulur Gelung Teratai. Journal of Urban Society's Arts, 5(1), 37-48. 
Panofsky, E. (1955). Meaning of The Visual Arts. Doubleday Anchor Books.

Rahmat, D. (2020). Garis keturunan Sunan Drajat dan salah satu penulis buku Sejarah Sunan Drajat Dalam Jaringan Masuknya Islam di Nusantara, di Desa Kranji, Kecamatan Paciran, Lamongan.

Rony. (2014). Ikonografi Arsitektur dan Interior Masjid Kristal Khadija Yogyakarta. Journal of Urban Society's Arts, 1(2), 121-134. https://doi.org/10.24821/jousa.v1i2.793

Sadah, K., D, A. H., \& Sachari, A. (2018). Kandungan Nilai Ajaran "Memangun Resep Tiyasing Sasama" Pada Ragam Hias Gerbang Kompleks Makam Sunan Drajat. Jurnal Islam Nusantara, 2(2), 162.

https://doi.org/10.33852/jurnalin.v2i2.9 1

Sumardjo, J. (2006). Estetika Paradoks. Sunan Anbu Press.

Sunaryo, A. (2009). Ornamen Nusantara: kajian khusus tentang ornamen Indonesia. Dahara Prize.

Sunyoto, A. (2018). Atlas Wali Songo. Pustaka IIMaN.

Tim Peneliti dan Penyusun Buku Sejarah Sunan Drajat. (1998). Sejarah Sunan Drajat Dalam Jaringan Masuknya Islam di Nusantara. . PT. Bina Ilmu Surabaya.

Toekio, S. (2000). Mengenal Ragam Hias Indonesia (Angkasa (ed.)).

Yumarma, A. (2012). Konsep Manusia Dalam Gunungan: Sebuah Refleksi Filosofis Terhadap Kearifan Lokal. Jurnal Filsafat, 22(1), 18-30. https://doi.org/10.22146/jf.12983 